\title{
Lesser Cornstalk Borer, Elasmopalpus lignosellus (Zeller) (Insecta: Lepidoptera: Pyralidae) ${ }^{1}$
}

John L. Capinera ${ }^{2}$

\section{Distribution}

This species occurs widely in the western hemisphere and is known from much of the southern United States. Despite its wide distribution, damage is limited principally to sandy soil, so it tends to cause injury in the coastal plain of the southeastern states from South Carolina to Texas.

\section{Description and Life Cycle}

There are three to four generations annually in the southeast, but in the southwest there are only three generations annually. Activity extends from June to November, with the generations overlapping considerably and little evidence of breaks between generations. Overwintering apparently occurs in the larval and pupal stage; diapause is not present. A complete life cycle usually requires 30 to 60 days.

Egg: The egg is oval, measuring about $0.6 \mathrm{~mm}$ in length and $0.4 \mathrm{~mm}$ in width. When first deposited, the egg is greenish, soon turning pinkish, and eventually reddish. The female deposits nearly all her eggs below the soil surface, adjacent to plants. A few, however, are placed on the surface or on leaves and stems. Duration of the egg stage is two to three days.
Larva: Larvae live in the soil, constructing tunnels from soil and excrement tightly woven together with silk. They leave the tunnel to feed in the basal stalk area or just beneath the soil surface, returning and constructing new tunnels as they mature. Thus, tunnels often radiate out from the stem of the food source, just below the soil surface. Normally there are six instars. During the early instars, larvae are yellowish green, with reddish pigmentation dorsally, tending to form transverse bands. As the larva matures, whitish longitudinal stripes develop, so that by the fifth instar they are pronounced. The mature larva is bluish green, but tends toward reddish brown with fairly distinct yellowish white stripes dorsally. The head capsule is dark in color, and measures about $0.23,0.30,0.44$, $0.63,0.89$, and $1.2 \mathrm{~mm}$ in width, respectively, for instars one through six. Larval lengths are about 1.7, 2.7, 5.7, 6.9, 8.8, and $16.2 \mathrm{~mm}$, respectively. Mean development time is estimated at 4.2, 2.9, 1.4, 3.1, 2.9, and 8.8 days for instars one through six, respectively. Total larval development time varies widely, but normally averages about 20 days.

Pupa: At larval maturity, the larva constructs a pupal cell of sand and silk at the end of one of the

1. This document is EENY-155, one of a series of Featured Creatures from the Entomology and Nematology Department, Florida Cooperative Extension Service, Institute of Food and Agricultural Sciences, University of Florida. Published: September 2000. This document is also available on Featured Creatures Website at http://creatures.ifas.ufl.edu. Please visit the EDIS Website at http://edis.ifas.ufl.edu. Additional information on these organisms, including many color photographs, is available at the Entomology and Nematology Department website at http://entnemdept.ifas.ufl.edu/.

2. John L. Capinera, professor/chairman, Entomology and Nematology Department, University of Florida, Gainesville, FL.

The Institute of Food and Agricultural Sciences is an equal opportunity/affirmative action employer authorized to provide research, educational information and other services only to individuals and institutions that function without regard to race, color, sex, age, handicap, or national origin. For information on obtaining other extension publications, contact your county Cooperative Extension Service office. Florida Cooperative Extension Service/Institute of Food and Agricultural Sciences/University of Florida/Christine Taylor Waddill, Dean. 


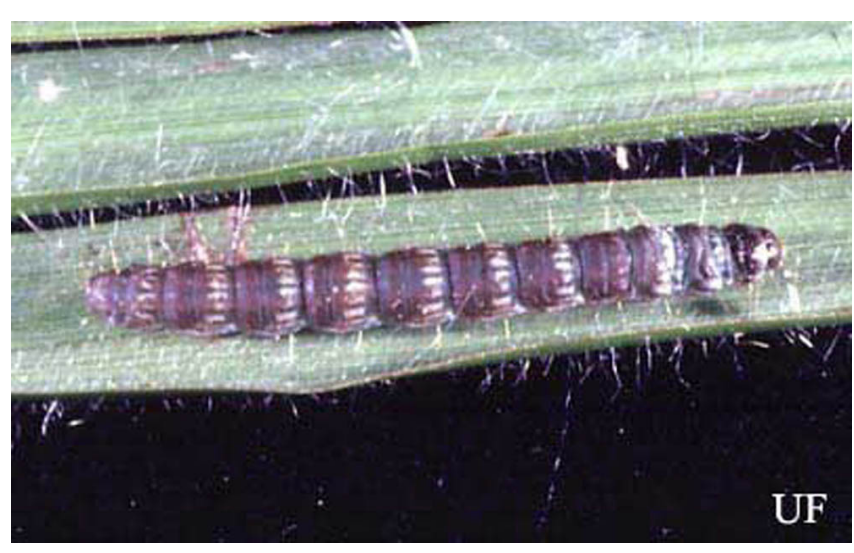

Figure 1. Mature larva of the lesser cornstalk borer, Elasmopalpus lignosellus (Zeller). Credits: John L. Capinera, University of Florida

tunnels. The cocoon measures about $16 \mathrm{~mm}$ in length and $6 \mathrm{~mm}$ in width. The pupa is yellowish initially turning brown and then almost black just before the adult emerges. It measures about $8 \mathrm{~mm}$ long and 2 $\mathrm{mm}$ wide. The tip of the abdomen is marked by a row of six hooked spines. Pupal development time averages about nine to 10 days, with a range of seven to13 days.

Adult: Moths are fairly small, measuring 17 to $22 \mathrm{~mm}$ in wingspan. Sexual dimorphism is pronounced. The forewing of the male moth is yellowish centrally, bordered by a broad dark band bearing purplish scales. In females, however, the entire forewing is dark, sometimes almost black, but also bearing reddish or purplish scales. The thorax is light in males, but dark in females. The hind wings of both sexes are transparent with a silvery tint. Adults are most active at night when the temperature exceeds 27 degrees $\mathrm{C}$, relative humidity is high, and there is little air movement. Such conditions are optimal for mating and oviposition. Females produce about 200 eggs. Adult longevity under field conditions is estimated at about 10 days.

\section{Host Plants}

Lesser cornstalk borer damages several crops grown in the southeast, although legume and grass crops are most often damaged. Mostly it is a pest of peanut, sorghum, and soybean. Among vegetable crops injured are bean, beet, cabbage, cantaloupe, corn, cowpea, lima bean, pea, pepper, sweet potato, tomato, and turnip. Field crops injured are corn, chufa, millet, oat, rice, rye, sorghum, peanut,

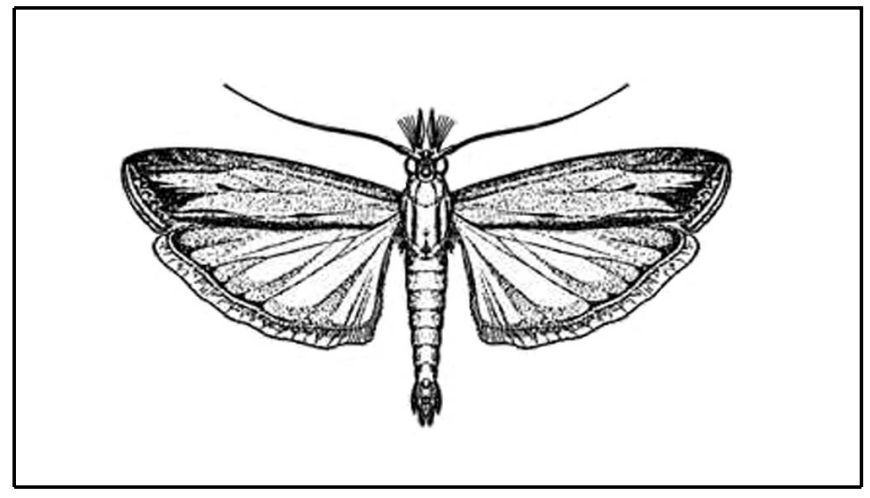

Figure 2. Adult moth.

soybean, sudangrass, sugarcane, and wheat. It also infests crabgrass, Digitaria sanguinalis, wiregrass, Elusine indica; and Johnsongrass, Sorghum halepense.

\section{Natural Enemies}

Several natural enemies of lesser cornstalk borer are known, though they are not thought to be major determinants of population trends. Smith and Johnson (1989) constructed life tables for populations in Texas, and identified survival of large larvae as the key element in generation survival, but the causative factor remains unidentified. The predominant parasitoids are Orgilus elasmopalpi Muesebeck and Chelonus elasmopalpi McComb (both Hymenoptera: Braconidae), Pristomerus spinator (Fabricius) (Hymenoptera: Ichneumonidae), and Stomatomyia floridensis Townsend (Diptera: Tachinidae) through most of the range of lesser cornstalk borer. Other parasitoids sometimes present include Bracon gelechiae Ashmead (Hymenoptera: Braconidae), Geron aridus Painter (Diptera: Bombyliidae), and Invreia spp. (Hymenoptera: Chalcididae). Parasitoids rarely cause more than $10 \%$ mortality.

Among the predators thought to be important mortality factors are a ground beetle, Plilophuga viridicolis LeConte (Coleoptera: Carabidae), Geocoris spp. bugs (Hemiptera: Lygaeidae), and larval stiletto flies (Diptera: Therevidae).

Pathogens are commonly present in lesser cornstalk borer populations. The most important pathogen appears to be a granulosis virus, but a Beauveria sp. fungus, microsporidia, and mermithid nematodes also have been found (Funderburk et al. 1984). 


\section{Weather}

Lesser cornstalk borer seems to be adapted for hot, xeric conditions, and therefore tends to be more abundant and damaging following unusually warm, dry weather. Mack et al. (1993) used data from Alabama and Georgia to develop a predictive equation that forecasts the potential for crop injury and the need to monitor crops. It is based on the concept of "borer-days." Borer-days is calculated as the sum of days during the growing season in which the temperature equals or exceeds 35 degrees $\mathrm{C}$ and the precipitation is less than $2.5 \mathrm{~mm}$, less the number of days in which the temperature is less than 35 degrees $\mathrm{C}$ and the precipitation equals or exceeds 2.5 $\mathrm{mm}$. Thus, it is the sum of the number of hot, dry days less the number cooler, wetter days. If the number of borer-days equals or exceeds 10 , damage is likely. If borer days equals 5-9 then damage is possible and fields should be scouted. The relationship between borer-days and larval abundance is nonlinear, and small increases in borer-days beyond 10 results in large increases in larval abundance.

\section{Damage}

The larval stage causes damage when it feeds upon, and tunnels within, the stems of plants. Normally the tunneling is restricted to the basal region of stalks, including the belowground portion, and girdling may occur. In affected plants wilting is one of the first signs of attack, but buds may wither, and stunting and plant deformities are common. Plant death is not uncommon, and infested areas of fields often have a very thin stand.

\section{Management}

\section{Sampling}

The egg stage is difficult to sample because eggs are small and resemble sand grains. Eggs can be separated by flotation, however. Larval populations are aggregated, and can be separated from soil by sieving or flotation (Mack et al. 1991). Adults are attracted to light traps, but are difficult to monitor with this technique because the moths of lesser cornstalk borer are difficult to distinguish from many other species. This is especially true of the females, which are less distinctive than the males. Pheromone

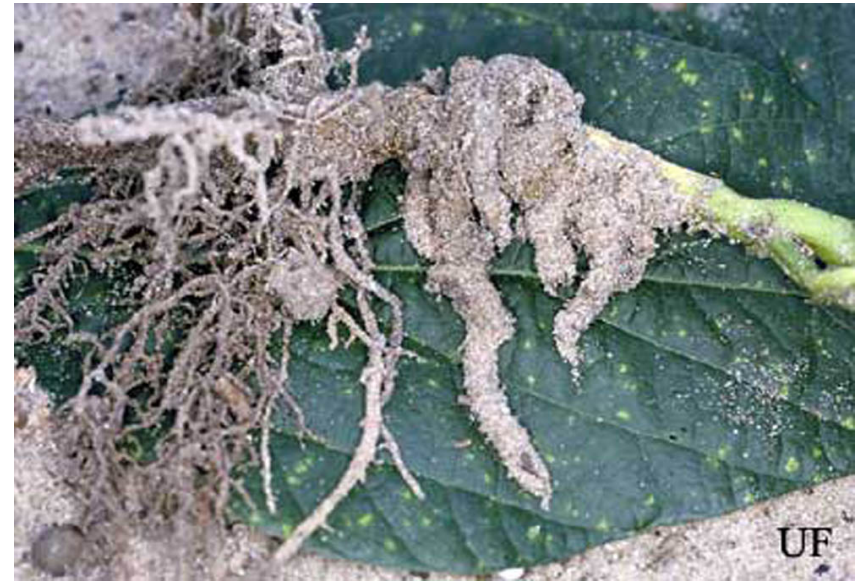

Figure 3. Soil tubes formed by the lesser cornstalk borer, Elasmopalpus lignosellus (Zeller). Credits: University of Florida

traps have been used successfully to monitor adult populations, and adults can be flushed from fields by beating the vegetation. Adult pheromone trap catches and flush counts are correlated (Funderburk et al. 1985). Adult and larval counts are often highly correlated, indicating that flush counts can be used to predict the abundance of larvae in subsequent weeks.

\section{Insecticides}

Insecticides applied for suppression of lesser cornstalk borer are usually applied in a granular formulation in the seed furrow or in a band over the seed bed. Liquid formulations can also be applied, but it is important that they be directed to the root zone.

Insect Management Guide for Vegetables (http://edis.ifas.ufl.edu/MENU_IG:Vegetables)

Insect Management Guide for Field Crops (http://edis.ifas.ufl.edu/MENU_IG:Field_Crops_ and_Pastures)

\section{Cultural Practices}

Modified planting practices have long been used to minimize crop loss. Populations tend to increase over the course of a season, so some damage can be avoided by early planting. Tillage and destruction of weeds are recommended prior to planting because this helps to destroy larvae that may be present in the soil and might damage seedlings, the stage most susceptible to destruction. However, crop culture that uses conservation tillage (i.e., retention of crop residue at the soil surface) experiences less injury 
from lesser cornstalk borer feeding because the larvae feed freely on crop residue and other organic matter, sparing the young crop plants (All et al. 1979).

\section{Selected References}

- All, J.N., R.N. Gallaher, and M.D. Jellum. 1979. Influence of planting date, preplanting weed control, irrigation, and conservation tillage practices on efficacy of planting time insecticide applications for control of lesser cornstalk borer in field corn. J. Econ. Entomol. 72:265-268.

- Capinera, J.L. 2001. Handbook of Vegetable Pests. Academic Press, San Diego. 729 pp.

- Funderburk, J.E., D.G. Boucias, D.C. Herzog, R.K. Sprenkel, and R.E. Lynch. 1984. Parasitoids and pathogens of larval lesser cornstalk borers (Lepidoptera: Pyralidae) in northern Florida. Environ. Entomol.

13:1319-1323.

- Funderburk, J.E., D.C. Herzog, T.P. Mack, and R.E. Lynch. 1985. Sampling lesser cornstalk borer (Lepidoptera: Pyralidae) adults in several crops with reference to adult dispersion patterns. Environ. Entomol. 14:452-458.

- Leuck, D.B. 1966. Biology of the lesser cornstalk borer in south Georgia. J. Econ. Entomol. 59:797-801.

- Luginbill, P. and G.G. Ainslie. 1917. The lesser cornstalk borer. USDA Bull. 539. 27 pp.

- Lynch, R.E., J.A. Klun, B.A. Leonhardt, M. Schwarz, and J.W. Garner. 1984b. Female sex pheromone of the lesser cornstalk borer, Elasmopalpus lignosellus (Lepidoptera: Pyralidae). Environ. Entomol. 13:121-126.

- Mack, T.P., D.P. Davis, and C.B. Backman. 1991. Predicting lesser cornstalk borer (Lepidoptera: Pyralidae) larval density from estimates of adult abundance in peanut fields. J. Entomol. Sci. 26:223-230.

- Mack, T.P., D.P. Davis, and R.E. Lynch. 1993. Development of a system to time scouting for the lesser cornstalk borer (Lepidoptera: Pyralidae) attacking peanuts in the southeastern United States. J. Econ. Entomol. 86:164-173.

- Smith, Jr., J.W. and S.J. Johnson. 1989. Natural mortality of the lesser cornstalk borer (Lepidoptera: Pyralidae) in a peanut agroecosystem. Environ. Entomol. 18:69-77.

- Smith, Jr., J.W., S.J. Johnson, and R.L. Sams. 1981. Spatial distribution of lesser cornstalk borer eggs in peanuts. Environ. Entomol. 10:192-193.

- Tippins, H.H. 1982. A review of information on the lesser cornstalk borer Elasmopalpus lignosellus (Zeller). Georgia Agric. Exp. Stn. Spec. Publ. 17. 65 pp. 